\title{
MINERAL RESOURCE POTENTIAL OF BUNK ROBINSON PEAK AND WHITMIRE CANYON ROADLESS AREAS, HIDALGO COUNTY, NEW MEXICO, AND COCHISE COUNTY, ARIZONA
}

\author{
By
}

\author{
P. T. Hayes, K. C. Watts, and J. R. Hassemer, \\ U.S. Geological Survey, \\ and S. Don Brown, U.S. Bureau of Mines
}

\section{STUDIES RELATED TO WILDERNESS}

Under the provisions of the Wilderness Act (Public Law 88-577, September 3, 1964) and the Joint Conference Report on Senate Bill 4, 88th Congress, the U.S. Geological Survey and the U.S. Bureau of Mines have been conducting mineral surveys of wilderness and primitive areas. Areas officially designated as "wilderness," "wild," or "canoe" when the act was passed were incorporated into the National Wilderness Preservation System, and some of them are presently being studied. The act provided that areas under consideration for wilderness designation should be studied for suitability for incorporation into the Wilderness System. The mineral surveys constitute one aspect of the suitability studies. The act directs that the results of such surveys are to be made available to the public and be submitted to the President and the Congress. This report discusses the results of a mineral survey of the Bunk Robinson Peak and Whitmire Canyon Roadless Areas (U.S. Forest Service areas 3-200 and 3-110, respectively), Coronado National Forest, Hidalgo County, N. Mex., and Cochise County, Ariz. The areas were established as study areas by Public Law $96-550$.

\section{MINERAL RESOURCE POTENTIAL SUMMARY STATEMENT}

Geologic (Hayes, 1982) and geochemical (Watts and others, 1983) investigations and a survey of existing mines and mineral claims (S. D. Brown, unpub. data, 1980) have been conducted to determine the mineral resource potential of the Bunk Robinson Peak and the Whitmire Canyon Roadless Areas, Hidalgo County, N. Mex., and Cochise County, Ariz. The roadless areas lie in the southern part of the Peloncillo Mountains within the Coronado National Forest. The outcrops in most parts of the roadless areas are rhyolitic lavas and tuffs and related latiticdacitic lavas and tuffs, volcanic and sedimentary breccias, and finer grained volcaniclastic rocks of Oligocene age. The volcanic rocks were probably vented from in or near the mapped area in Oligocene time, possibly from a volcanic cauldron. Other rocks in the roadless areas are younger Miocene(?) volcanic rocks, sandstone, and conglomerate and minor basaltic lava of Pleistocene or Pliocene age.

The investigations did not reveal any minable mineral deposits near the surface within the boundaries of the roadless areas, but geochemical data and alteration studies indicated possible undiscovered metallic deposits at depth. The most likely area for such deposits is beneath a hydrothermally altered area in the northwest part of the Bunk Robinson Peak Roadless Area. Volcanic vent areas or buried igneous stocks in the southwest part of the Whitmire Canyon Roadless Area and the northeast part of the Bunk Robinson Peak Roadless Area also offer moderate potential for undiscovered metallic deposits at depth. There may also be a moderate potential for perlite deposits within the roadless areas, but there seems to be low potential for other nonmetalliferous deposits or for oil or gas.

\section{INTRODUCTION}

Location, size, and geographic setting

The Bunk Robinson Peak and the Whitmire Canyon Roadless Areas of the Coronado National Forest straddle the Arizona-New Mexico state line in the southern Peloncillo Mountains (fig. 1). They are separated by a mile-wide zone containing a road (the Geronimo Trail) that crosses the mountains. The southerly Bunk Robinson Peak Roadless Area comprises about $30 \mathrm{mi}^{2}$ mostly in Hidalgo County,
N. Mex., but has a little more than $1 \mathrm{mi}^{2}$ extending into Cochise County, Ariz. The northerly Whitmire Canyon Roadless Area comprises about $18 \mathrm{mi}^{2}$ of which about $11 \mathrm{mi}^{2}$ lie in New Mexico and about seven in Arizona. The terrane in both areas is characterized by cliffs and steep slopes, but the total relief is not great. The highest altitudes above sea level are 6,450 $\mathrm{ft}$ in the Bunk Robinson Peak Roadless Area (on Guadalupe Mountain) and $6,526 \mathrm{ft}$ in the Whitmire Canyon Roadless Area (at Peloncillo triangulation station), and the lowest altitudes are about 4,600 ft in the Bunk Robinson Peak Roadless Area (in Guadalupe 


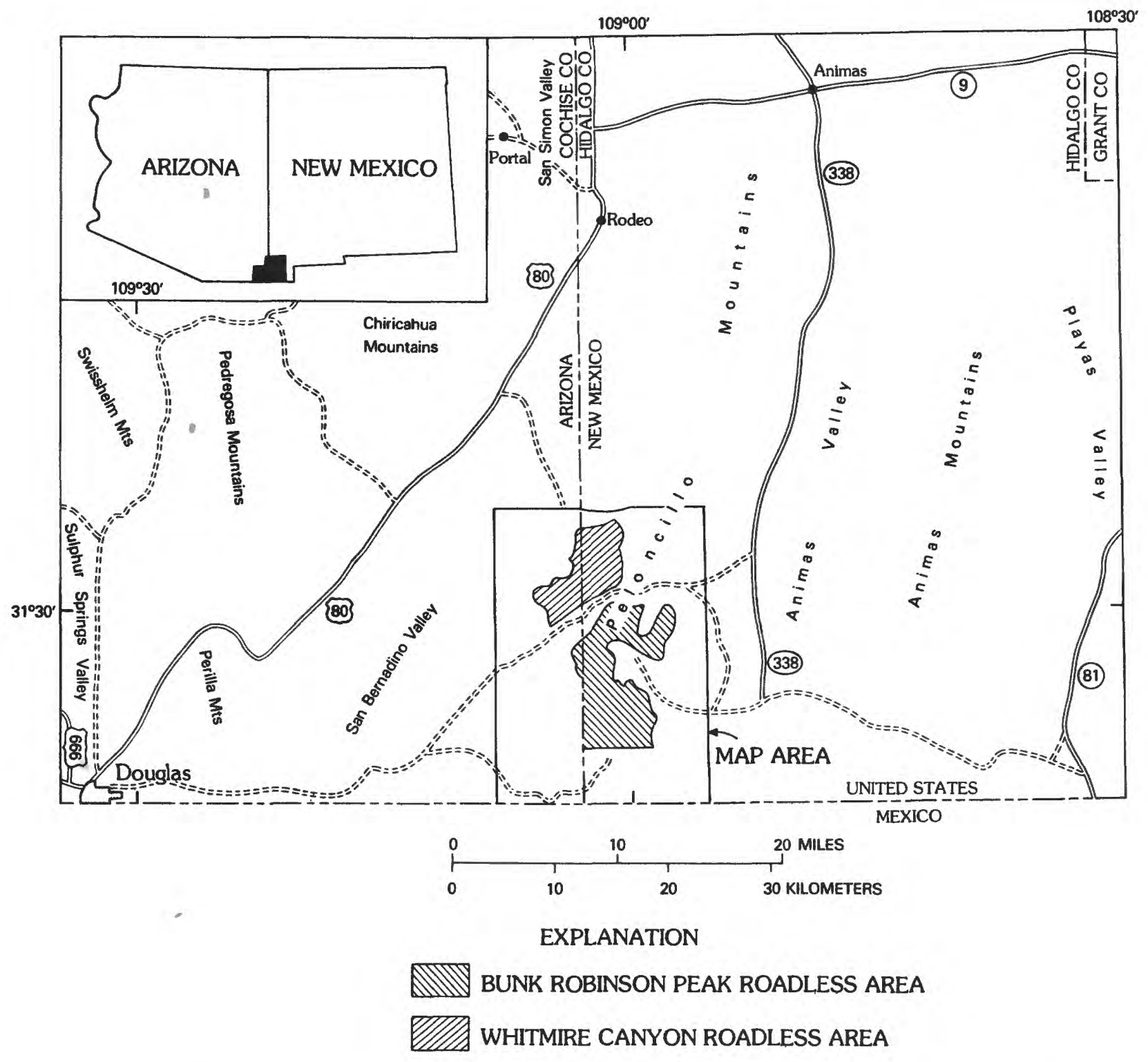

Figure 1.--Index map showing location of Bunk Robinson Peak and Whitmire Canyon Roadless Areas (U.S. Forest Service areas 3-200 and 3-110, respectively) 

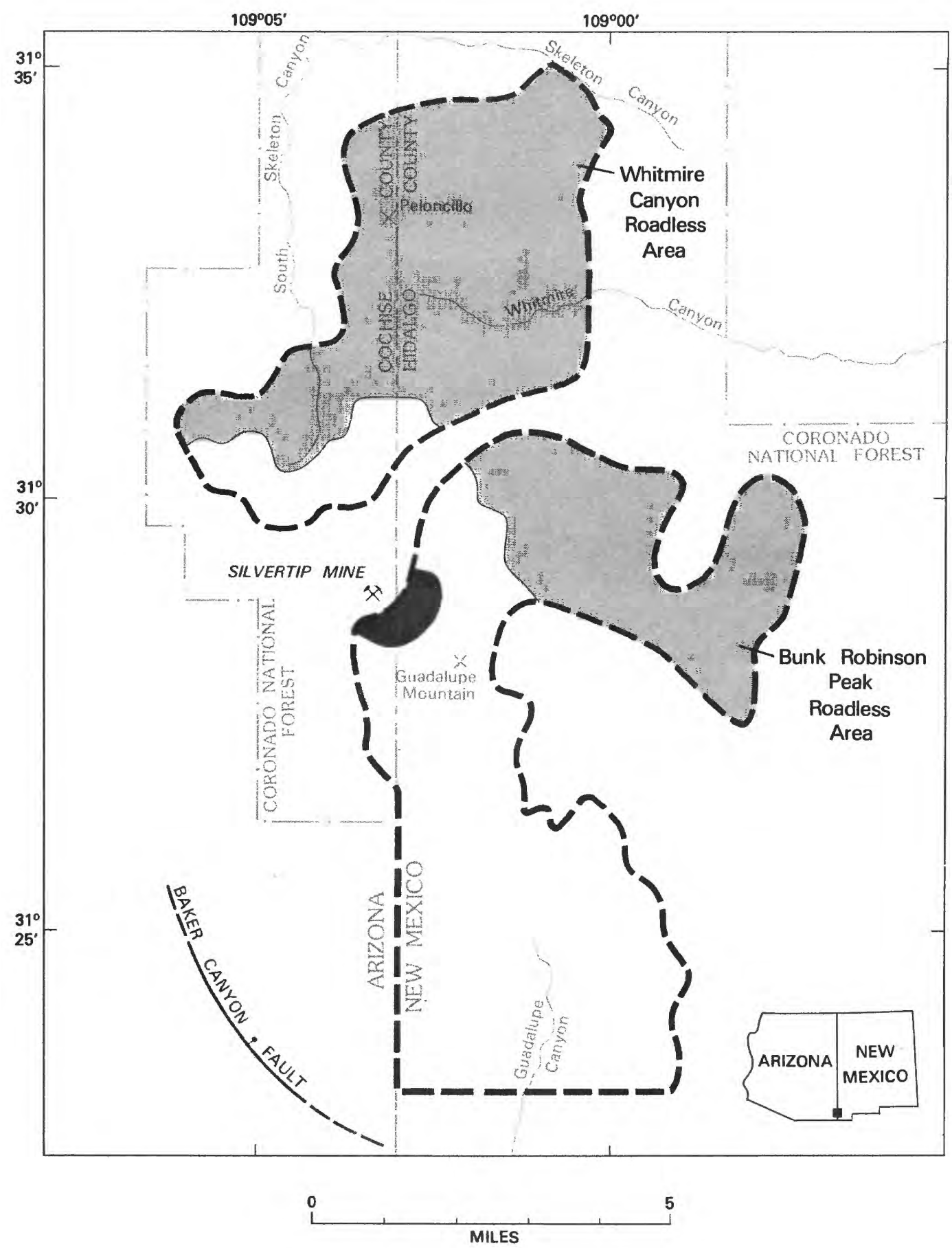

\section{EXPLANATION}

Area of altered rock and geochemical anomalies that has potential for undiscovered metal deposits at depth

Areas largely underlain by rhyolite lava that could contain local undiscovered metal deposits at depth

Approximate boundary of roadless areas as of April 9, 1980

Figure 2.--Map showing areas of mineral resource potential in Bunk Robinson Peak and Whitmire Canyon Roadless Areas 
Canyon) and about 5,100 ft in the Whitmire Canyon Roadless Area (in Skeleton Canyon).

\section{Previous studies and present investigation}

Except for the most cursory of examinations, the southern part of the Peloncillo Mountains, in which the Bunk Robinson Peak and the Whitmire Canyon Roadless Areas are located, were not geologically mapped until the late 1950 's, and then only by reconnaissance. The Arizona part of the mountains was mapped by Cooper (1959) and, soon after, the New Mexico part was mapped by Wrucke and Bromfield (1961). The first and only detailed mapping of the roadless areas was done by Erb (1979). The geologic map used in the present investigation (Hayes, 1982) was taken largely from the three earlier maps, especially that of Erb, after field checking in the spring of 1980. A few modifications of Erb's mapping were made by generalizing the geologic units, making minor additions and deletions of small faults, and reconnaissance remapping of several square miles southwest of the Bunk Robinson Peak Roadless Area. In conjunction with the geologic mapping and field checking, a search was made for evidence of mineralization. In addition to the geologic work, the present study entailed an examination of mines and prospects near the roadless areas by the U.S. Bureau of Mines (S. D. Brown, unpub. data, 1980). A final important part of the present investigation was a geochemical study of the roadless areas and surroundings. The geochemical field sampling was done in 1980 by Kenneth C. Watts and Jerry S. Hassemer who were assisted in subsequent laboratory analysis of the samples by Gordon W. Day (Watts and others, 1983).

\section{GEOLOGIC SETTING}

The Peloncillo Mountains, in which the Bunk Robinson Peak and the Whitmire Canyon Roadless Areas lie, were probably elevated to their present position by mid- to late Tertiary Basin and Range-type faulting. About 80 percent of the outcropping rock in the two areas is rhyolitic tuff and lava of Oligocene age, with tuff being dominant in the Bunk Robinson Peak Roadless Area and lava being dominant in the Whitmire Canyon Roadless Area. Other rocks in the two areas consist of dacitic lava, quartz latitic lava and tuff, volcanic breccias, and diverse epiclastic rocks also of Oligocene age. Some tuffaceous sandstone and conglomerate containing interlayered tuff of probable Miocene age lie near the northeast corners of both roadless areas, and small remnants of Pleistocene or Pliocene olivine basaltic lava cap some higher hills in both roadless areas. The rhyolitic lavas and tuffs and related rocks almost certainly were vented from one or more nearby volcanic centers. Deal and others (1978) and Erb (1979) postulate that a large volcanic cauldron was centered near the middle of the mapped area. The Baker Canyon fault (west of the southern part of the Bunk Robinson Peak Roadless Area) is believed to be part of a ring-fracture system on the southwest margin of the cauldron (Erb, 1979). No other arcuate faults are evident, but lava domes near the head of South Fork Skeleton Canyon are postulated by Erb (1979) to have vented along the northwest margin of the cauldron, whereas an arcuate band of lava domes on a ridge in the northeast part of the Bunk Robinson Peak Roadless Area is postulated to define the northeast margin of the cauldron. There are a dozen or so north-trending faults within the roadless areas, most of which may be related to cauldron collapse but some of which have shown displacement since emplacement of the Pleistocene or Pliocene basaltic lava. Drewes (1978) has postulated that the Peloncillo Mountains are part of a large prevolcanic thrust plate related to the late Mesozoic and early Cenozoic Cordilleran orogeny. Whether or not such is the case, any Paleozoic or Mesozoic sedimentary rocks that may underlie the mountains must have been shattered and baked to some extent by the Oligocene volcanism.

\section{MINING ACTIVITY}

No mining activity was conducted in or near the Bunk Robinson Peak and Whitmire Canyon Roadless Areas during the time of our study, but there has been some recent prospecting. During the spring of 1980 , an exploration firm, under contract from a petroleum company, was doing geophysical work near the roadless areas.

A search of courthouse records revealed that about 90 mining claims, most of them near the Silvertip mine, had been located in the mapped area. The Silvertip mine, $1 / 3 \mathrm{mi}$ outside the northwest boundary of the Bunk Robinson Peak Roadless Area, consists of a 240-ft-long adit and a 30-ft-deep shaft in a 10-ft-thick mineralized fracture zone (S. D. Brown, unpub. data, 1980). The mine dumps contain about 80 tons of rock though no ore minerals were recognized. No mining records could be found for the Silvertip mine, suggesting that if there ever was precious metal production it probably was not substantial.

A small abandoned rock quarry lies between the roadless areas; the rock quarried was rhyolite tuff that was used locally for building stone.

About $9 \mathrm{mi}^{2}$ of each of the roadless areas have been leased for oil and gas exploration. In addition, oil- and gas-lease applications are pending for about $20 \mathrm{mi}^{2}$ in the Bunk Robinson Peak Roadless Area and for about $7 \mathrm{mi}^{2}$ in the Whitmire Canyon Roadless Area.

\section{GEOCHEMISTRY}

Results of the geochemical investigations of this study (Watts and others, 1983) do not directly indicate the presence of any important mineral deposits, but anomalous values of a half dozen elements in three general areas are noteworthy. An area of altered (kaolinized?) rock near the Silvertip mine that extends into the Bunk Robinson Peak Roadless Area was found to contain higher than normal values of barium, lead, and arsenic. In addition, spring water in this altered area was found to be very acidic and to contain anomalous amounts of aluminum, sulfate, manganese, iron, molybdenum, and zinc. A large area underlain by rhyolitic lava, that covers much of the Whitmire Canyon Roadless Area and several square miles in the northeast part of the Bunk Robinson Peak Roadless Area, shows anomalously high values of tin, related to the visually identified mineral cassiterite $\left(\mathrm{SnO}_{2}\right)$, in heavy mineral concentrates of stream-sediment 
samples. Molybdenum shows higher than normal values in much of the area covered by rhyolitic lava, and beryllium, bismuth, lead, and zinc are locally abnormally abundant within the rhyolitic lava. An arcuate area near the Baker Canyon fault, west of the Bunk Robinson Peak Roadless Area, showed higher than normal values of tin, beryllium, and barium. All of the above, if not directly indicative of minable metallic deposits, add to the surface geologic evidence for a buried igneous stock or a metallized volcanic cauldron being centered in the mapped area and having genetic affinities to tin-molybdenum mineralization. As suggested by Elston (1978), many of the mining districts of southwestern New Mexico seem to be directly related to volcanic cauldrons of mid-Tertiary age.

\section{ASSESSMENT OF MINERAL RESOURCE POTENTIAL}

\section{Base and precious metals}

There are no direct indications of minable deposits containing base or precious metals in the Bunk Robinson Peak or Whitmire Canyon Roadless Areas. However, kaolinized(?) surface rock, metal-rich acid waters, and anomalously high values of barium, lead, molybdenum, and arsenic in an area that extends into the Bunk Robinson Peak Roadless Area from the vicinity of the Silvertip mine (fig. 2), indicate mineralizing hydrothermal activity occurred in that area. Consequently, it is possible that minable deposits containing molybdenum, bismuth, lead, zinc, or possibly precious metals could be discovered in the subsurface of the Bunk Robinson Peak Roadless Area by drilling. Similar altered rock, acid waters, and anomalously high values of barium near the Baker Canyon fault, which is just west of the southern part of the Bunk Robinson Peak Roadless Area, indicate hydrothermal activity occurred there, too. Anomalously high values of tin, molybdenum, beryllium, and bismuth in areas underlain by rhyolitic lava in both roadless areas (fig. 2) are not indicative of minable mineral deposits at the surface, but do suggest the possibility of the presence of mineralized igneous rock at depth.

\section{Nonmetalliferous deposits}

No important nonmetalliferous deposits were found within the Bunk Robinson Peak or the Whitmire Canyon Roadless Areas. However, layers of obsidian as much as $8 \mathrm{ft}$ thick are present locally in the rhyolitic lava outcrops in both roadless areas. The presence of obsidian suggests that the area could also contain perlite deposits. Perlite is used as lightweight aggregate. Rhyolite tuff between the roadless areas has been quarried for building stone for local house construction.

\section{Oil and gas}

Sedimentary rocks of Paleozoic and Cretaceous ages that could conceivably contain hydrocarbon reservoirs may underlie the Bunk Robinson Peak and the Whitmire Canyon Roadless Areas at depth
(Thompson and others, 1978). Sam Thompson III (written commun., July 19, 1982) reports that natural gas in Permian rocks and dead oil in Ordovician rocks have been encountered in exploratory holes drilled about $30 \mathrm{mi}$ to the east of the roadless areas. However, the volcanic activity that was located in or near the roadless areas would almost certainly have had a deleterious effect on any oil or gas that may once have been present beneath the roadless areas. For that reason, the oil and gas potential of the roadless areas is considered poor.

\section{REFERENCES CTIED}

Cooper, J. R., 1959, Reconnaissance geologic map of southeastern Cochise County, Arizona: U.S. Geological Survey Mineral Investigations Field Studies Map MF-213, scale 1:125,000.

Deal, E. G., Elston, W. E., Erb, E. E., Peterson, S. L., Reiter, D. E., Damon, P. E., and Shafiqullah, M., 1978, Cenozoic volcanic geology of the Basin and Range Province in Hidalgo County, southwestern New Mexico, in Callender, J. F., and others, eds., Land of Cochise; southeastern Arizona: New Mexico Geological Society Guidebook, 29th Field Conference, p. 219-229.

Drewes, Harald, 1978, The Cordilleran orogenic belt between Nevada and Chihuahua: Geological Society of America Bulletin, v. 89, p. 641-657.

Elston, W. E., 1978, Mid-Tertiary cauldrons and their relationship to mineral resources, southwestern New Mexico; a brief review, in Field guide to selected cauldrons and mining districts of the Datil-Mogollon volcanic field, New Mexico: New Mexico Geological Society Special Publication No. 7, p. 107-113.

Erb, E. E., Jr., 1979, Petrologic and structural evolution of ash-flow tuff cauldrons and noncauldron-related volcanic rocks in the Animas and southern Peloncillo Mountains, Hidalgo County, New Mexico: University of New Mexico, $\mathrm{Ph}$. D. thesis, $286 \mathrm{p}$.

Hayes, P. T., 1982, Geologic map of Bunk Robinson Peak and Whitmire Canyon Roadless Areas, Coronado National Forest, New Mexico and Arizona: U.S. Geological Survey Miscellaneous Field Studies Map MF-1425-A, scale 1:62,500.

Thompson, Sam, III, Tovar R., J. C., and Conley, J. N., 1978, Oil and gas exploration wells in the Pedregosa Basin, in Callender, J. F., and others, eds., Land of Cochise; southeastern Arizona: New Mexico Geological Society Guidebook, 29th Field Conference, p. 331-342.

Watts, K. C., Hassemer, J. R., and Day, G. W., 1983, Geochemical maps of Bunk Robinson Peak and Whitmire Canyon Roadless Areas, Coronado National Forest, New Mexico and Arizona: U.S. Geological Survey Miscellaneous Field Studies Map MF-1425-C, scale 1:62,500.

Wrucke, C. T., and Bromfield, C. S., 1961, Reconnaissance geologic map of part of the southern Peloncillo Mountains, Hidalgo County, New Mexico: U.S. Geological Survey Mineral Investigations Field Studies Map MF-160, scale $1: 62,500$. 
